International Journal of Social Science (IJSS)

Vol.1 No.2 August 2021, pp: 69-78

ISSN: 2798-3463 (Printed) | 2798-4079 (Online)

DOI: https://doi.org/10.53625/ijss.v1i2.138

\title{
PRODUCT QUALITY AND CUSTOMER SATISFACTION AND THEIR EFFECT ON CONSUMER LOYALTY
}

\author{
By \\ Ernest Grace', Rosita Manawari Girsang ${ }^{2}$, Sudung Simatupang ${ }^{3}$, \\ Vivi Candra ${ }^{4}$, Novelyn Sidabutar ${ }^{5}$ \\ 1,3,4,5Sekolah Tinggi Ilmu Ekonomi Sultan Agung \\ ${ }^{2}$ Fakultas Ekonomi/ Universitas Simalungun \\ Email: ${ }^{1}$ ernestgrace87@ gmail.com, ${ }^{2}$ rosita.girsang@gmail.com, ${ }^{3}$ selitaefraim@ gmail.com, \\ 4vfitrawan@ gmail.com, ${ }^{5}$ novelynsidabutar49@ gmail.com

\begin{tabular}{l}
\hline \hline Article Info \\
\hline Article history: \\
Received May 8, 2021 \\
Revised June 27, 2021 \\
Accepted July 23, 202 \\
\\
\hline Keywords: \\
Product Quality \\
Customer Satisfaction \\
Consumer Loyalty
\end{tabular}

\begin{abstract}
The results of this study are to see whether the influence of product quality and customer satisfaction on consumer loyalty is found at Mandiri Jaya Mobil Pematangsiantar whose business is engaged in buying and selling new and used cars, with a total of 130 consumers and using validity, reliability, normality test, and analysis instruments. the coefficient of determination, as well as simple and multiple regression equations as well as the $t$ hypothesis test and $\mathrm{F}$ test. Then a conclusion is generated that for the partial hypothesis answer it is found that the influence of product quality variables has a positive and significant effect on consumer loyalty then consumer satisfaction has a positive and significant effect on consumer loyalty and for the simultaneous test to produce answers to the hypothesis that simultaneously there is a positive and significant influence on product quality and consumer satisfaction on consumer loyalty. This shows that when product quality is getting better, and satisfaction is achieved, loyalty will persist.
\end{abstract} \\ ABSTRACT
}

Corresponding Author:

Ernest Grace

Sekolah Tinggi Ilmu Ekonomi Sultan Agung

Email: ernestgrace87@ gmail.com
This is an open access article under the CC BY-SA license.

\section{INTRODUCTION}

The marketing model in the current era of globalization is the key to the success process, to be able to achieve this success process requires the ability to do good marketing with the aim of making the company profit, as well as in the marketing of automotive products. The development of the industry in the automotive business world today is so rapid, this happens because of the influence of the attractive growth of the automotive industry and the positive growth results in the life of the middle class in the last decade(Hidayah, 2019) and the automotive industry is one of the sectors that produces a form of contribution significant for the economy on a national scale (Sirait, 2020) and these results require business people in the automotive industry to strive to maintain the viability of their business with all the efforts and strengths they have, in other words entrepreneurs are required to attract consumers' interest and maintain it as a consumers who are loyal to the company's products (Saputra, 2016). Through marketing activities whose purpose is to influence consumers to want to buy their products with the achievement of consumer loyalty. The ability provided by the business sector can at least maintain the loyalty of its consumers, so that the ability to dominate the market can be maintained later according to (Aristyo, 2019) it is necessary to have a strategy in maintaining consumer loyalty.

Consumer loyalty can occur because of the commitment from customers to a brand, store, supplier through a positive attitude and a reflection in repeated purchasing activities, because according to (Sodexo, 2019) customer loyalty is a very important asset for a company and how to get it is also difficult. because the emergence of consumer 
loyalty can arise from 2 aspects, namely loyalty from brands and stores (Putri, 2017). Loyalty can be achieved not only with the 4 P's marketing mix, namely: product, price, location and promotion but also with people, the process, the programs carried out and performance (Kotler and Keller, 2016)

Mandiri Jaya Mobil Pematangsiantar also hopes for the emergence of consumer loyalty. which is engaged in the automotive sector, for its business activities buying and selling used and new cars with various types such as minibuses, pick ups, to trucks. As a result of the increasingly fierce level of competition between similar competitors, this business has made adjustments to its marketing strategy to answer the challenge of consumer loyalty. To maintain customer loyalty, Mandiri Jaya Mobil implements the stages of the process: making purchases continuously then buying between product/service lines, referring products to others, and showing immunity to similar competitors (Griffin, 2005). However, the problem with the level of consumer loyalty is still said to be low due to continuous purchases because there are consumers who only buy a car once. To buy between product/service lines, the lowest results are obtained. This is due to the fact that there are still consumers who do not use the services offered, such as car salon services and vehicle tax management, then referencing products to others and getting low results because there are still consumers who do not want to invite friends or his family to buy a car in this place, and to show immunity to competitors is still low because there are still consumers who are not consistent in buying cars at Mandiri Jaya Mobil

Seeing this, it is necessary to increase consumer loyalty with various factors that influence it, one of which is product quality, this is in line with research (Permatasari, 2014) that one way to increase consumer loyalty is to increase product quality and true loyalty lies with consumers, because quality the product is the main input (Lovelock, Wirtz and Mussry, 2016)() meaning that if the quality of the product is appropriate then consumer loyalty will also increase and vice versa (Aprileny and Regar, 2018). Product quality is measured based on performance, features, reliability, conformance to specifications, durability, serviceability, aesthetics and quality (Tjiptono and Chandra, 2011)but the phenomenon found that for durability is that it is still found selling cars with years low so that the durability of the car cannot be guaranteed. In aesthetics, it still provides products that are still limited in color alternatives so that it makes it difficult for prospective consumers to choose the color they want, because they still focus on existing stock and the dimensions of ease of repair (service ability) related to the ease of repairing vehicles and services provided by Mandiri Jaya Mobil Pematangsiantar .

In addition to product quality, the satisfaction factor of consumers can affect consumer loyalty, in line with research (Widjojo, 2013) meaning that when consumer satisfaction increases, the consumer loyalty factor will increase (Minarti and Segoro, 2014) where one aspect that affects loyalty is satisfaction. that occurs from the comparison between expectations before making a purchase with expectations of performance (Zikmund, 2003). Consumer satisfaction found at the research location that the price of the product is still there are consumers who feel less satisfied because the price level offered by the party is still too high. For the convenience of the procedure, consumers are satisfied because it is easy to apply for a car loan and assist in the credit process until it is approved by the leasing party. While on the dimension of consumer support, employees are less enthusiastic in receiving any complaints from consumers and there are still some complaints that cannot be resolved immediately.

Paying attention to the problems above, it becomes the basis of the research objective to determine the effect of product quality and consumer satisfaction on consumer loyalty.

\section{LITERATURE REVIEW \\ Product quality}

Product quality is the main focus which is a very important policy in increasing the competitiveness of products in order to provide satisfaction to consumers (Raharjo, 2013) and product quality has a close relationship with the product's ability to carry out its functions, including overall product, reliability, accuracy, easy to operate and repair as well as attributes that have other values (Kotler and Amstrong, 2012), product quality reflects all dimensions that generate benefits for customers (Tjiptono, 2015). The products offered by business entities will be different and must have characteristics that differ from those of their competitors, even though the types have similarities (Putro, Semuel and Karina, 2014). This means that the quality of a product will determine whether or not consumers are satisfied with the purchase and use of the product (Hidayat, 2009).

\section{Consumer Satisfaction}

Consumer satisfaction arises from performance expectations in meeting customer satisfaction needs, if they feel satisfied then it results from appropriate performance expectations, if performance exceeds expectations, customers will be more satisfied (Setyaji and Ngatno, 2016) and consumer satisfaction can be measured, so that the company have the ability to see the level of consumer satisfaction with strategies that seek to create consumer satisfaction(Wono, Angela and Reinal, 2020) in satisfaction theory there are 2 models, namely functional and psychological satisfaction 
International Journal of Social Science (IJSS)

Vol.1 No.2 August 2021, pp: 69-78

ISSN: 2798-3463 (Printed) | 2798-4079 (Online)

DOI: https://doi.org/10.53625/ijss.v1i2.138

where functional satisfaction occurs when the product is in line with expectations, while psychological satisfaction is felt in the form of not have a form but can feel satisfaction (Kaihatu, Daengs and Indrianto, 2015).

Consumer Loyalty

(Griffin, 2005) (Griffin, 2005) explains that loyalty arises from buyer behavior, where customer satisfaction can be accepted by consumers when the company provides real loyalty (Aryani and Rosinta, 2010) The status pattern of consumer loyalty is divided into 4 groups, namely: consumers who are very loyal, somewhat loyal, switching and diverting loyalty Saputra, 2016), loyalty refers to feelings, or emotional bonds, which make a person bind himself to an organization or brand (Saputra, 2016) (Faranisa, Sudjiono and Girahani, 2018).

\section{Thinking Framework}

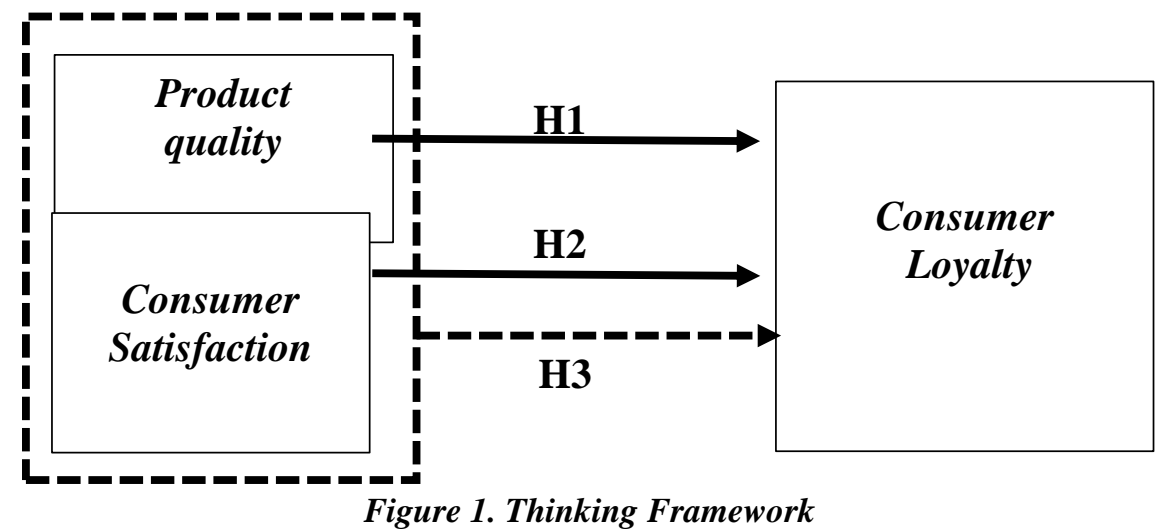

Hypothesis

The hypotheses that can be given in this study are:

1. H1 : That product quality has a partial influence on consumer loyalty Mandiri Jaya Mobil Pematangsiantar.

2. H2 : That consumer satisfaction has a partial influence on consumer loyalty Mandiri Jaya Mobil Pematangsiantar.

3. H3 : That product quality and consumer satisfaction have a simultaneous influence on consumer loyalty Mandiri Jaya Mobil Pematangsiantar.

\section{RESEARCH METHODS}

The research location is on Jalan Jendral Ahmad Yani No. 73, with a Trading Business License (SIUP) No. 503/68/SIUP-KECIL/DPMPTSP/11/2018 and a Company Registration Certificate (TDP) No. 02.05.5.45.00170. with the business name Mandiri Jaya Mobil Pematangsiantar, it is engaged in the sale and purchase of new and used cars and the number of consumers who have researched 130 . The analytical tool used is to test the validity by testing the validity by comparing the value of the correlation coefficient $>$ critical $=0.30$ (Barker, Pistrang and Elliott, 2016) then reliability by comparing the minimum reliability level of Cronbach's alpha > 0.70 (Eisingerich and Rubera, 2010); then the normality test is carried out by comparing the asymp values. sig. (2-tailed) $>0.05$, the coefficient of determination is used to see how much the independent variable is able to explain the dependent variable. Then using simple and multiple linear equations with the aim of seeing the effect of the independent variable on the dependent variable and using the $\mathrm{t}$ test to answer the hypothesis partially and the $\mathrm{F}$ test to answer the simultaneous test.

\section{RESULTS AND DISCUSSION}

\section{Validity and Reliability Test}

Validity test

The usefulness of this validity test is to determine the accuracy and accuracy of a measuring instrument in measuring the measured data. The results of the validity test of this study are shown in the following table.

Table 1. Validity Test

\begin{tabular}{|l|r|r|c|}
\hline \multicolumn{1}{|c|}{ Variable } & $\begin{array}{c}\text { Corrected Item- } \\
\text { Total Correlation }\end{array}$ & \multicolumn{1}{c|}{$\boldsymbol{t}_{\text {critical }}$} & Criteria \\
\hline Product quality & 0,563 & 0,30 & Valid \\
\hline Consumer Satisfaction & 0,667 & 0,30 & Valid \\
\hline
\end{tabular}




Lonsumer Loyalty $\quad 0,617 \quad 0,30$ Valid

Source: Data processing, 2021

The results from table 1 can be explained that the three research variables, product quality, customer satisfaction and customer loyalty are declared to have valid criteria, this is because they are in accordance with the provisions that the correlation value of arithmetic > from critical 0.30 .

\section{Reliability Test}

The usefulness of the reliability test is to determine the reliability of the questionnaire items conducted in the study. The results of the reliability test of this study can be seen in the following table.

Table 2. Reliability Test

\begin{tabular}{|l|c|c|c|}
\hline \multicolumn{1}{|c|}{ Variable } & Cronbach's Alpha & $\begin{array}{c}\text { Level } \\
\text { Reliability }\end{array}$ & Criteria \\
\hline Product Quality & 0,899 & 0,70 & Reliability \\
\hline Consumer satisfaction & 0,886 & 0,70 & Reliability \\
\hline Consumer Loyalty & 0,889 & 0,70 & Reliability \\
\hline
\end{tabular}

Source: Data processing, 2021

Table 2 shows the results of reliability testing with the statement that all research variables namely product quality, customer satisfaction and consumer loyalty that the value of Cronbach's alpha > from the reliability level of 0.70 , thus the research variable is declared reliable or reliable.

Normality

The purpose of the normality test is to assess the distribution of data that has a normal distribution or not. The results of the normality test can be seen in the following table.

Table 3. Normality Test

One-Sample Kolmogorov-Smirnov Test

\begin{tabular}{|c|c|c|c|c|}
\hline & & /Product Quality & $\begin{array}{c}\text { Consumer } \\
\text { Satisfaction }\end{array}$ & $\begin{array}{c}\text { Consumer } \\
\text { Loyalty }\end{array}$ \\
\hline \multicolumn{2}{|l|}{$\mathrm{N}$} & 130 & 130 & 130 \\
\hline \multirow{2}{*}{$\begin{array}{l}\text { Normal } \\
\text { Parameters }\end{array}$} & Mean & 65,56 & 31,37 & 42,35 \\
\hline & Std. Deviation & 10,717 & 7,024 & 8,402 \\
\hline \multirow{3}{*}{$\begin{array}{l}\text { Most Extreme } \\
\text { Differences }\end{array}$} & Absolute & ,107 & ,099 & ,088 \\
\hline & Positive &, 052 & 049 &, 060 \\
\hline & Negative &,- 107 &,- 099 &,- 088 \\
\hline \multicolumn{2}{|c|}{ Kolmogorov-Smirnov Z } & 1,223 & 1,129 & 1,004 \\
\hline \multicolumn{2}{|c|}{ Asymp. Sig. (2-tailed) } &, 101 &, 156 & ,266 \\
\hline
\end{tabular}

Source: Data processing, 2021

Table 3 shows the results that the value of asymp. sig. (2-tailed) each research variable of product quality, customer satisfaction and customer loyalty is normally distributed with reference to the asymp value. sig. (2-tailed) $>$ 0.05 , where for product quality variable the value is 0.101 , customer satisfaction variable is 0.158 and consumer loyalty is 0.266 .

\section{Coefficient of Determination.}

For the analysis of the coefficient of determination to see the suitability of a relationship form of the independent variable in explaining the dependent variable. To clarify the results can be seen in the following table.

Table 4. Analysis of the Coefficient of Determination

\begin{tabular}{|c|c|c|c|c|}
\hline Model & $\mathrm{R}$ & R Square & $\begin{array}{l}\text { Adjusted R } \\
\text { Square }\end{array}$ & $\begin{array}{l}\text { Std. Error of the } \\
\text { Estimate }\end{array}$ \\
\hline 1 & $.813^{a}$ & ,661 & 656 & 4,930 \\
\hline
\end{tabular}

Source: Data processing, 2021

Table 4 shows the results that the R Square value of the research is 0.661 , which means that the ability of the independent variable to product quality, consumer satisfaction in explaining the independent variable of consumer 
International Journal of Social Science (IJSS)

Vol.1 No.2 August 2021, pp: 69-78

ISSN: 2798-3463 (Printed) | 2798-4079 (Online)

DOI: https://doi.org/10.53625/ijss.v1i2.138

loyalty is $66 \%$ while the remaining $34 \%$ are not discussed in this study such as product design, price. and so on, while the correlation value of $\mathrm{R}$ shows a value of $81 \%$ in the sense that the correlation is strong.

Multiple Linear Regression

Multiple linear aims to determine the effect of two independent variables, namely product quality, consumer satisfaction on the dependent variable, in this case consumer loyalty. The results of multiple regression testing can be seen in the table below.

Table 5. Multiple Linear Regression Coefficients $^{\mathbf{a}}$

\begin{tabular}{|l|l|r|r|r|r|}
\hline \multicolumn{2}{|l|}{ Model } & \multicolumn{2}{|c|}{ Unstandardized Coefficients } & \multicolumn{1}{|c|}{$\begin{array}{c}\text { Standardized } \\
\text { Coefficients }\end{array}$} & \multirow{2}{*}{ Sig } \\
\cline { 3 - 5 } \multicolumn{2}{|l|}{} & \multicolumn{1}{|c|}{ B } & Std. Error & \multicolumn{1}{c|}{ Beta } & \\
\hline \multirow{2}{*}{1} & (Constant) & 2,026 & 2,693 & &, 453 \\
\cline { 2 - 5 } & Product Quality &, 454 &, 062 &, 580 &, 000 \\
\cline { 2 - 5 } & Consumer Satisfaction &, 336 &, 095 &, 281 &, 001 \\
\hline
\end{tabular}

a. Dependent Variable: Consumer Loyalty

Source: Data processing, 2021

The results of the equation in table 5 show the value of $\mathrm{Y}=2.026+0.454 \mathrm{X} 1+0.336 \mathrm{X} 2$, which means that if the constant value of product quality increases by one (1) unit, then consumer loyalty will increase by 0.454 and a significant value of product quality $0.00<0,05$, as well as when consumer satisfaction increases by one (1) unit, then loyalty also increases by 0.336 and a significant value of $0.001<0.05$. The conclusion is that product quality and consumer satisfaction have a positive and significant effect on consumer loyalty, and the biggest influence on consumer loyalty is the product quality variable. Because consumers will feel satisfied or happy and continue to repurchase when the product purchased is in accordance with expectations, the wishes that have been conveyed about the product are due to the nature of consumers today having a tendency to choose products that have features with better advantages.

\section{Hypothesis Testing}

\section{Partial Test (t Test)}

Partial test was conducted to see the effect of each independent variable on the dependent variable. To clarify the results of the partial test hypothesis, see the table below.

H1 : There is an Influence of Product Quality on Consumer Loyalty

Table 6. Partial Test 1

\begin{tabular}{|c|c|c|c|}
\hline \multicolumn{2}{|c|}{ Model } & t & \\
\hline 1 & (Constant) &, 752 & ,453 \\
\hline & Product quality & 7,319 &, 000 \\
\hline
\end{tabular}

Source: Data processing, 2021

The results from table 6 show that the tcount value of product quality is 7,319 , with reference to the calculation of ttable $\mathrm{df}=(\mathrm{n}-\mathrm{k})=1,978$. The conclusion is that the product quality variable tcount 7,319>1,978 and significant product quality count $0.000<0.05$, which means accepting the $\mathrm{H} 1$ hypothesis that there is an effect of product quality on consumer loyalty.

The quality of a product is highly expected by the company in maintaining its business life, with good product quality, consumers who come to buy the product are satisfied and will give a form of loyalty from themselves not to switch to other products, because the conditions are very difficult for the company at this time. is to create good product quality because many competitors provide good product quality as well (Rahayu and Haryanto, 2017). For this reason, loyalty from consumers is needed for companies, because retaining consumers means being able to maintain the viability of the company (Wulandari, Sri Wardiningsih and Widajanti, 2016); because consumers will like products that offer quality and other things that are different from other products (Wahyudien, Widiartanto and Listyorini, 2015). Thus, product quality can affect consumer loyalty (Raharjo, 2013); (Zuhri, 2019), meaning that when the value of product quality increases or gets better, consumer loyalty also increases (Permatasari, 2014); (Jesika, Juniarsih and Astika, 2020). However, research differs (Hidayat, 2009)) that the better the quality of the product does not necessarily make consumers have loyalty and (Wantara and Tambrin, 2019) which states that the quality of the product has no effect on 
loyalty. This can happen because the consumer has previously been disappointed when buying a product in the previous time, after the company has made quality improvements, consumers still have trauma from past events.

H2 : There is an Influence of Consumer Satisfaction on Consumer Loyalty

Table 7. Partial Test 2

\begin{tabular}{|l|l|r|r|}
\hline \multicolumn{2}{|c|}{ Model } & \multicolumn{2}{|c|}{ Sig. } \\
\hline \multirow{2}{*}{1} & (Constant) &, 752 &, 453 \\
\cline { 2 - 4 } & Consumer Satisfaction & 3,543 &, 001 \\
\hline
\end{tabular}

Source: Data processing, 2021

The results from table 7 show that the tcount value of consumer satisfaction is 3.543 with reference to the calculation of ttable $\mathrm{df}=(\mathrm{n}-\mathrm{k})=1.978$. The conclusion is that the tcount of the consumer satisfaction variable is 3.543 $>1.978$ and the significance of the calculated consumer satisfaction is $0.001<0.05$, which means accepting the $\mathrm{H} 2$ hypothesis that there is an influence of consumer satisfaction on consumer loyalty.

Satisfying consumer needs becomes the desire of a company to be a factor in the company's survival and satisfaction of consumer needs can be a benchmark of excellence in facing competition. Consumers who are satisfied with the product or service tend to repurchase the product or service at the time of the same need in the future (Riadi, 2013); and can increase the loyalty of consumers to recommend to other consumers to come to make a purchase (Widjojo, 2013), because the aspect that affects loyalty is satisfaction which is a comparison between expectations before making a purchase and the performance that has been suggested (Zikmund, 2003). This means that when consumers are satisfied with the products, prices, services of a company, it will affect the loyalty of these consumers and these consumers will remain loyal to use the products of the company, this is in line with research (Amalia, 2013); (Molle, Mandey and Kojo, 2019); (Minarti and Segoro, 2014), but consumer satisfaction may not have a significant effect on consumer loyalty (Faranisa, Sudjiono and Girahani, 2018) this can occur when consumer satisfaction when it comes to buying products or services, the results of these products or services does not produce benefits for these consumers, causing disappointment for consumers and causing consumers to switch to other companies.

\section{Simultaneous Test (F Test)}

Simultaneous test is used to find out how all of the independent variables affect the independent variables and the regression model has a significant value or not (Hidayat, 2013). The test results of table F can be seen in the following table.

H3

: Effect of Product Quality and Consumer Satisfaction on Consumer Loyalty.

Tabel 8. Uji Simultan

Table 8. Simultaneous Test

\begin{tabular}{|ll|l|l|}
\hline & Model & F & \multicolumn{2}{|c|}{ Sig. } \\
\hline 1 & $\begin{array}{l}\text { Regression } \\
\text { Residual } \\
\text { Total }\end{array}$ & 123,883 & \\
\end{tabular}

Source: Data processing, 2021

Table 8 shows the results for simultaneous hypothesis testing with reference Fcount $>$ Ftable. With consumers as research respondents the number is 130 . For Fcount has a value of 123,883 and a value of Ftable (k:nk) where $\mathrm{k}$ is the independent variable of product quality and consumer satisfaction and $\mathrm{n}$ is the number of respondents as many as 130 , then the results for Ftable are $(2: 130-2)=(2: 128)=3.07$. Based on table 8, it can be concluded that the Fcount $123,883>$ Ftable 3.07 and the significance value $0.000<0.05$, as the basis for the simultaneous test decision, the $\mathrm{H} 3$ hypothesis is accepted that there is an effect of product quality and consumer satisfaction on consumer loyalty simultaneously.

Every company always wants to produce products that have good quality with the aim of being able to compete with other companies, and it should be noted that product quality is not seen from the company's view but from the perspective of the customers (Razak, Nirwanto and Triatmanto, 2016); consumer satisfaction can be in the form of feeling happy or disappointed with product performance as expected (Syafarudin, 2021); then consumer satisfaction is also expected by the company in order to create a harmonious relationship for the basis of being a repurchase to create loyalty (De Ruyter, Wetzels and Bloemer, 1998) in other words satisfaction can be associated 
International Journal of Social Science (IJSS)

Vol.1 No.2 August 2021, pp: 69-78

ISSN: 2798-3463 (Printed) | 2798-4079 (Online)

DOI: https://doi.org/10.53625/ijss.v1i2.138

with loyalty (Waari, 2018)( Product quality and customer satisfaction have a close relationship because together they are able to provide benefits for the company, the consistency of a product or service quality can contribute to the company's success based on the satisfaction of its consumers (Sitanggang, Sinulingga and Fachruddin, 2019). This means that product quality and consumer satisfaction have an influence on the loyalty of consumers who come to buy products or services from the company, this is in line with research (Rua, Saldanha and Amaral, 2020); (Ali et al., 2020); If product quality and satisfaction are achieved for a consumer, it will result in good loyalty and loyalty from these consumers.

\section{CONCLUSIONS AND SUGGESTIONS}

The conclusion obtained from the results of this study that product quality and consumer satisfaction have a positive and significant effect either partially or simultaneously on consumer loyalty Mandiri Jaya Mobil Pematangsiantar. This shows that the quality of a product is able to provide confidence for consumers because consumers today really want products that have good quality, are not easily damaged, as well as if consumers are satisfied it will produce a positive impression for consumer loyalty, because satisfied consumers will definitely come back to buy another time.

The company should always maintain the quality of the products and services it produces, it is very useful for the survival of the company to further strive optimally to produce consumers who have high loyalty while maintaining what is the company's advantage.

\section{REFERENCES}

[1] Ali, M. et al. (2020) 'The Influence of Brand Trust and Product Quality on Customer Satisfaction and Its Implication on Consumer Loyalty at the Branch office of Pt . Bank Indonesia ( Persero ) Tbk . Banda Aceh , Indonesia', East African Scholars Journal of Economics, Business and Management, 3(4), pp. 3-8. doi: 10.36349/EASJEBM.2020.v03i04.001.

[2] Amalia, L. (2013) 'Analisis Hubungan Kepuasan Dengan Loyalitas Konsumen Terhadap Sepeda Motor Yamaha Vixion Pada Bengkel Abadi', Jurnal Ekonomi Universitas Esa Unggul Jakarta, 4(November), pp. 113. Available at: https://www.neliti.com/id/publications/17897/analisis-hubungan-kepuasan-dengan-loyalitaskonsumen-terhadap-sepeda-motor-yamah.

[3] Aprileny, I. and Regar, Y. (2018) 'ANALISIS PENGARUH KUALITAS PRODUK, CITRA MEREK, DAN KEPUASAN KONSUMEN TERHADAP LOYALITAS KONSUMEN (STUDI KASUS PADA JCO DONUTS \&COFFEE MKG)', Jurnal Akuntansi dan Manajemen, 14(2), pp. 13-44.

[4] Aristyo, R. (2019) 4 Strategi BMW Astra Jaga Loyalitas Konsumen di Indonesia, https://www.inews.id. Available at: https://www.inews.id/otomotif/mobil/4-strategi-bmw-astra-jaga-loyalitas-konsumen-di-indonesia (Accessed: 6 April 2021).

[5] Aryani, D. and Rosinta, F. (2010) 'Pengaruh Kualitas Layanan terhadap Kepuasan Pelanggan dalam Membentuk Loyalitas Pelanggan', Bisnis \& Birokrasi,Jurnal Ilmu Administrasi dan Organisasi, 17(2), pp. 114 126. Available at: http://journal.ui.ac.id/index.php/jbb/article/view/632/617.

[6] Barker, C., Pistrang, N. and Elliott, R. (2016) Research Methods in Clinical Psychology: An Introduction for Students and Practitioners (3rd ed.). Edition: 3. England: John Wiley \& Sons Ltd. doi: 10.1002/9781119154082.

[7] Eisingerich, A. B. and Rubera, G. (2010) 'Drivers of Brand Commitment: A Cross-National Investigation', Journal of International Marketing, 18(2), pp. 64-79. doi: 10.1509/jimk.18.2.64.

[8] Faranisa, D., Sudjiono and Girahani, E. (2018) 'PENGARUH KEPUASAN KONSUMEN DAN KEPERCAYAAN MEREK TERHADAP LOYALITAS KONSUMEN PRODUK SEPEDA MOTOR HONDA (Studi Kasus Pada Galaxy Motor Kediri)', JIMEK, 1(1), pp. 126-138.

[9] Griffin, J. (2005) Customer loyalty: menumbuhkan dan mempertahankan kesetiaan pelanggan. Jakarta: Erlangga.

[10] Hidayah, S. N. (2019) Geliat, Prospek, dan Tantangan Industri Otomotif Indonesia, https://www.gaikindo.or.id. Available at: https://www.gaikindo.or.id/geliat-prospek-dan-tantangan-industri-otomotif-indonesia/ (Accessed: 3 April 2021).

[11] Hidayat, A. (2013) Uji $F$ dan Uji $T$, https://www.statistikian.com. Available at: https://www.statistikian.com/2013/01/uji-f-dan-uji-t.html\#: :text=Uji F dikenal dengan Uji,bersama-sama terhadap variabel terikatnya. (Accessed: 1 June 2021). 
[12] Hidayat, R. (2009) 'Pengaruh Kualitas Layanan, Kualitas Produk dan Nilai Nasabah Terhadap Kepuasan dan Loyalitas Nasabah Bank Mandiri', Jurnal Manajemen dan Kewirausahaan, 11(1), pp. 59-72. doi: 10.9744/jmk.11.1.pp.59-72.

[13] Jesika, S., Juniarsih, D. and Astika, Y. W. (2020) 'PENGARUH KUALITAS PRODUK KOSMETIK BATRISYIA TERHADAP LOYALITAS KONSUMEN', HIRARKI Jurnal Ilmiah Manajemen dan Bisnis, 2(2), pp. 126-130.

[14] Kaihatu, T. S., Daengs, A. and Indrianto, A. T. L. (2015) Manajemen Komplain. Yogyakarta: Andi.

[15] Kotler, P. and Amstrong, G. (2012) Prinsip-prinsip Pemasaran. Edisi 13. Jakarta: Erlangga.

[16] Kotler, P. and Keller, K. (2016) Marketing Management. 15th Editi. New Jersey: Pearson Pretice Hall, Inc.

[17] Lovelock, C., Wirtz, J. and Mussry, J. (2016) Pemasaran Jasa: Perspektif Indonesia. Jakarta: Erlangga.

[18] Minarti, S. N. and Segoro, W. (2014) 'The Influence of Customer Satisfaction, Switching Cost and Trusts in a Brand on Customer Loyalty - The Survey on Student as im3 Users in Depok, Indonesia', Procedia - Social and Behavioral Sciences, 143, pp. 1015-1019. doi: 10.1016/j.sbspro.2014.07.546.

[19] Molle, M. A., Mandey, S. I. and Kojo, C. (2019) 'Pengaruh Kepuasan Konsumen Terhadap Loyalitas Konsumen Pada Royalâ $€^{\mathrm{TM}} \mathrm{S}$ Resto and Function Hall Di Kota Ternate', Jurnal EMBA: Jurnal Riset Ekonomi, Manajemen, Bisnis dan Akuntansi, 7(1), pp. 871-880. doi: 10.35794/emba.v7i1.22917.

[20] Permatasari, D. N. (2014) 'ANALISIS PENGARUH KUALITAS PRODUK DAN BAURAN PROMOSI TERHADAP LOYALITAS KONSUMEN SMARTPHONE BLACKBERRY (Studi pada Mahasiswa di Beberapa Universitas di Jakarta) Dewi', Jurnal MIX, IV(1), pp. 57-69.

[21] Putri, B. D. A. (2017) Apa yang dimaksud dengan Loyalitas Merek atau Brand Loyalty?, https://www.dictio.id. Available at: https://www.dictio.id/t/apa-yang-dimaksud-dengan-loyalitas-merek-atau-brand-loyalty/14011 (Accessed: 3 April 2021).

[22] Putro, S. W., Semuel, H. and Karina, R. M. R. B. (2014) 'Pengaruh Kualitas Layanan Dan Kualitas Produk Terhadap Kepuasan Pelanggan Dan Loyalitas Konsumen Restoran Happy Garden Surabaya', Jurnal Manajemen Pemasaran, 2(1), pp. 1-9. Available at: http://publication.petra.ac.id/index.php/manajemenpemasaran/article/view/1404.

[23] Raharjo, A. (2013) 'Pengaruh Kualitas Produk Terhadap Loyalitas Konsumen Yang Dimediasi Oleh Kepuasan Konsumen Pengguna Kartu AS', SEGMEN Jurnal Manajemen dan Bisnis, 9(1), pp. 1-12. Available at: http://ejournal.umpwr.ac.id/index.php/segmen/article/view/365.

[24] Rahayu, S. and Haryanto, J. (2017) 'Pengaruh Kualitas Produk Terhadap Keputusan Pembelian Pada Majalah Media Asuransi', Jurnal Pemasaran Kompetitif, 1(1), pp. 64-76.

[25] Razak, I., Nirwanto, N. and Triatmanto, B. (2016) 'The Impact of Product Quality and Price on Customer Satisfaction with the Mediator of Customer Value', Journal of Marketing and Consumer Research, 30(2012), pp. 59-68.

[26] Riadi, M. (2013) Pengertian, Faktor dan Pengukuran Kepuasan Konsumen, https://www.kajianpustaka.com. Available at: https://www.kajianpustaka.com/2013/04/pengertian-faktor-pengukuran-kepuasankonsumen.html (Accessed: 31 May 2021).

[27] Rua, S., Saldanha, E. D. S. and Amaral, A. M. (2020) 'Examining the Relationships among Product Quality, Customer Satisfaction and Loyalty in the Bamboo Institute, Dili, Timor-Leste', Timor Leste Journal of Business and Management, 2(1), pp. 33-44. doi: 10.51703/bm.v2i2.28.

[28] De Ruyter, K., Wetzels, M. and Bloemer, J. (1998) 'On The Relationship Between Perceived Service Quality, Service Loyalty And Switching Costs', International Journal of Service Industry Management, 9(5), pp. 436453. doi: $10.1108 / 09564239810238848$.

[29] Saputra, A. (2016) 'Analisis Pengaruh Atribut Produk Terhadap Loyalitas Konsumen (Studi Kasus Konsumen Toyota Agya Di Kota Medan)', JURNAL MANAJEMEN BISNIS STIE IBBI, 25(1), pp. 31-41. doi: 10.31227/osf.io/hsu9b.

[30] Setyaji, D. I. and Ngatno (2016) 'Pengaruh Kualitas Pelayanan dan Kepuasan Konsumen terhadap Loyalitas Pelanggan (Studi Kasus pada Pelanggan Go-Jek di Semarang)', JIAB- Jurnal Ilmu Administrasi Bisnis, 5(4), pp. 1-10. Available at: https://ejournal3.undip.ac.id/index.php/jiab/article/view/13566.

[31] Sirait, S. (2020) Pemerintah Indonesia Terus Meтаси Laju Industri Otomotif, https://www.carmudi.co.id. Available at: https://www.carmudi.co.id/journal/pemerintah-indonesia-terus-memacu-laju-industri-otomotif/ (Accessed: 3 April 2021).

[32] Sitanggang, J. M., Sinulingga, S. and Fachruddin, K. A. (2019) 'Analysis Of The Effect Of Product Quality On Customer Satisfaction And Customer Loyalty Of Indihome ATPT Telkom Regional 1 Sumatera, Medan, North Sumatra, Indonesia', American International Journal of Business Management (AIJBM, 2(3), pp. 26-37. 
International Journal of Social Science (IJSS)

Vol.1 No.2 August 2021, pp: 69-78

ISSN: 2798-3463 (Printed) | 2798-4079 (Online)

DOI: https://doi.org/10.53625/ijss.v1i2.138

[33] Sodexo (2019) Pentingnya Loyalitas dalam Bisnis: Bagaimana Loyalitas Bisa Meningkatkan Penjualan?, https://www.sodexo.co.id. Available at: https://www.sodexo.co.id/bagaimana-loyalitas-bisa-meningkatkanpenjualan/ (Accessed: 5 April 2021).

[34] Syafarudin, A. (2021) 'The Effect of Product Quality on Customer Satisfaction Implications on Customer Loyalty in the Era Covid-19', Ilomata International Journal of Tax and Accounting, 2(1), pp. 71-83. doi: 10.52728/ijtc.v2i1.204.

[35] Tjiptono, F. (2015) Strategi Pemasaran. Edition: 4. Yogyakarta: Andi.

[36] Tjiptono, F. and Chandra, G. (2011) Service Quality \& Satisfaction Service Quality and Statisfaction. Edisi-3. Yogyakarta: Andi.

[37] Waari, D. N. (2018) 'The Effect of Customer Satisfaction on Customer Loyalty: The Moderation Roles of Experiential Encounter And Customer Patronage', IOSR Journal of Business and Management (IOSR-JBM), 20(April), pp. 74-80. doi: 10.2139/ssrn.3393066.

[38] Wahyudien, I. K., Widiartanto and Listyorini, S. (2015) 'Pengaruh Kualitas Produk dan Kualitas Pelayanan terhadap Loyalitas Pelanggan Melalui Kepuasan Pelanggan sebagai Variabel Intervening ( Studi Kasus Pada Pelanggan Larissa Aesthetic Center Semarang )', Jurnal Ilmu Administrasi Bisnis (JiAB), 4(4), pp. 1-9. Available at: https://ejournal3.undip.ac.id/index.php/jiab/article/view/9290.

[39] Wantara, P. and Tambrin, M. (2019) 'ITHJ International Tourism and Hospitality Journal The Effect of Price and Product Quality Towards Customer Satisfaction and Customer Loyalty on Madura Batik', International Tourism and Hospitality Journal, 2(1), pp. 1-9. Available at: https://rpajournals.com/ithj:https://rpajournals.com/ithj.

[40] Widjojo, P. O. (2013) 'Pengaruh Persepsi Nilai Pelanggan Dan Kepuasan Konsumen Terhadap Loyalitas Konsumen Hypermart Pakuwon Trade Center Di Surabaya', Kajian Ilmiah Mahasiswa Manajemen, 2(4), pp. 1-5. Available at: http://journal.wima.ac.id/index.php/KAMMA/article/view/487.

[41] Wono, H. Y., Angela, M. and Reinal, M. I. (2020) 'Pengaruh Kualitas Pelayanan dan Kepuasan Konsumen Terhadap Loyalitas Konsumen CV Saga Selaras Pratama’, CHANNEL: Jurnal Komunikasi, 8(1), pp. 51-58. doi: 10.12928/channel.v8i1.15119.

[42] Wulandari, R., Sri Wardiningsih, S. and Widajanti, E. (2016) 'PENGARUH KUALITAS PRODUK, KUALITAS PELAYANAN DAN PROMOSI TERHADAP LOYALITAS KONSUMEN DENGAN KEPUASAN KONSUMEN SEBAGAI VARIABEL MODERASI (Studi Pada Konsumen Larissa Aesthetic Center Solo)', Jurnal Ekonomi dan Kewirausahaan, 16(Juni), pp. 242-252.

[43] Zikmund, W. G. (2003) Business Research Methods. Ed-7. Thomson/South-Western.

[44] Zuhri, R. R. S. (2019) Pengaruh Kualitas Produk Terhadap Loyalitas Konsumen Pada Produk Shampo Dove (Studi Pada Mahasiswa/i Fakultas Psikologi Universitas Sumatera Utara). UNIVERSITAS SUMATERA UTARA. Available at: http://repositori.usu.ac.id/bitstream/handle/123456789/10232/141301065.pdf?sequence=1\&isAllowed=y. 
